Patient consent for publication Not required.

Provenance and peer review Not commissioned; internally peer reviewed.

(C) Author(s) (or their employer(s)) 2019. No commercial re-use. See rights and permissions. Published by BMJ.

\section{Hydrodissection in the removal of deeply located etonogestrel implants}

The paper by Pillai ${ }^{1}$ on the use of hydrodissection in the removal of deep-seated implants is interesting. The risks of deep placement of Nexplanon are clear in this paper. Additionally such placement may contribute to migration of the device as was highlighted by the Medicines and Healthcare products Regulatory Agency. ${ }^{2}$ Hydrodissection is a recognised technique in surgery to define tissue planes, to separate anatomical structures and thereby facilitate safe surgery.

My interest in this paper is related to the not uncommon problem of error in deploying the implant in the subdermal plane. As the manufacturer of Nexplanon recommends, ${ }^{3}$ the device is deployed in the tunnel created by the injection of local anaesthetic. This hydrodissection opens the subdermal area and pushes the deeper neurovascular structures away from where the implant would be deposited. This is similar to the technique described and used by Pillai in separating the implant from adjacent neurovascular structures.

While some operators would not see the need for this recommended method, I commend it in the interests of safety.

\section{Kenneth Menon}

General Practice, The Ongar Health Centre, Ongar CM5 OAL, Essex, UK; kenmenon@aol.com

Correspondence to Dr Kenneth Menon, The Ongar Health Centre, Ongar CM5 0AL, UK; kenmenon@aol.com

Competing interests None declared. 